\title{
Determinants of Human Capital Intensity: An Empirical Analysis on Automotive Suppliers in Turkey
}

\section{Beşeri Sermaye Yoğunluğunun Belirleyicileri: Türkiye'de Otomotiv Tedarikçileri üzerine Ampirik Bir Analiz}

\author{
Alper SÖNMEZ ${ }^{1}$ \\ Selçuk Üniversitesi
}

\begin{abstract}
The purpose of the paper is to analyze the determinants of human capital intensity levels of the firms with emphasize on foreign ownership and R\&D activities, also to make a contribution to the scarce empirical literature in this subject. The evidence is based on a comprehensive firm-level survey data gathered through face-to-face questionnaire with the top executives of suppliers operating in Turkish automotive industry. The key findings can be summarized as: (1) foreign ownership is the only variable that has positive (and significant) impact on all senses of supplier's human capital intensity as expected; (2) the impact of foreign ownership on a supplier's human capital is higher for white collar intensity-(general) than for engineer intensity-(specific); (3) being an older or larger supplier negatively (and significantly) impacts a supplier's specific human capital intensity, while performing R\&D activities (having an R\&D department), and being a firsttier supplier impact positively (and significantly). These findings reveal that smaller and younger first-tier foreign suppliers performing R\&D activities employ more specific (engineers) human capital stock.
\end{abstract}

Keywords: Human Capital, Foreign Direct Investment, Technology Spillover, R\&D, Automotive Industry, Turkey.

JEL: F21, F23, J24, L62

\section{Özet}

Bu makalenin amacı yabancı sahiplik yapısı ve Ar-Ge faaliyetlerine vurgu yaparak, firmaların beşeri sermaye yoğunluk seviyelerini etkileyen faktörleri analiz etmek ve ayrıca bu alanda oldukça kıt olan yazına ampirik bir katkı yapmaktadır. Bulgular Türkiye otomotiv sektöründe faaliyet gösteren tedarikçi firmaların üst düzey yöneticilerinden yüz yüze anket çalışması ile toplanan firma düzeyinde kapsamlı anket verilerine dayanmaktadır. Çalışmaya ilişkin önemli bulgular şu şekilde özetlenebilir: (1) yabancı sahiplik, beklendiği gibi, tedarikçi firmaların beşeri sermaye yoğunlukları üzerine pozitif (anlamlı) etkiye sahip tek değişkendir; (2) yabancı sahipliğin tedarikçi firmanın beşeri sermaye yoğunluğu üzerine etkisi beyaz-yaka yoğunluğu-(genel) için daha yüksek,

\footnotetext{
${ }^{1}$ Yrd. Doç. Dr., Selçuk Üniversitesi, İktisat Bölümü, E-Mail: alpersonmez80@gmail.com
} 
mühendis yoğunluğu-(spesifik) için daha azdır; (3) daha yaşlı veya daha büyük ölçekli olmak bir tedarikçi firmanın spesifik beşeri sermaye yoğunluğunu negatif (anlamlı) etkilerken, Ar-Ge faaliyetlerinde bulunmak (Ar-Ge bölümüne sahip olmak) ve ilk kademe tedarikçi olmak spesifik beşeri sermaye yoğunluğunu pozitif (anlamlı) etkilemektedir. Bu bulgular Ar-Ge faaliyetlerinde bulunan, daha küçük ve yeni kurulan yabancı sermayeli ilk kademe tedarikçi firmaların daha spesifik (mühendis) beşeri sermaye stoku istihdam ettiklerini ortaya koymaktadır.

Anahtar Kelimeler: Beşeri Sermaye, Doğrudan Yabancı Yatırım, Teknoloji Yayılımları, Ar-Ge, Otomotiv Sektörü, Türkiye.

\section{Introduction}

Technological developments have fundamentally changed the world. In the new millennium, technology policies have steadily gained attention in the economic development process of the countries especially with the globalization which has also a positive effect on creating and diffusion of the technology. In the modern growth theories, the role of technological innovation as pointed out by Schumpeter (1934) occupies a highly important position. Today, empirical studies regarding the spillover of technological innovations and developments stemming from the human capital (Romer, 1986) have widely been conducted (Lee, 2008).

In modern economic growth theory, foreign direct investment (FDI), human capital and technology are the three main factors which play an important role in the action of economic growth and development of the countries (Romer, 1986; Dunning, 1993; Barro and Sala-i-Martin, 1995). According to this theory, the development process of a backward country depends on its absorptive capacity with respect to human capital stock (HCS). In this theory, economic development is described by a "catch-up" process which is depends on the acquisition of new technologies (Borensztein et. al., 1998). Hence, HCS plays a very determinant role in a country's economic growth (Kuznets, 1966). Furthermore, in adapting of new technologies from developed countries, "unconventional approaches", formulated by Nelson and Winter (1982) and interpreted in Dosi (1988), suggest that "indigenous technological efforts" of the firms in developing countries play a deterministic role (Lall, 1992). This approach also implies that markets are inefficient in the diffusion of technology. The main assumptions of the approach are that; (i) technology is constructed as a result of high R\&D and innovation activities at huge costs so it cannot be freely accessible and entirely transferrable across firms; (ii) they are secured by creator firms to block the diffusion of technology; (iii) the adaptation of the technologies created by receiver firms calls for high qualified human capital. These assumptions also clarify why there are differences among countries (firms) in terms of their technology capabilities (for further details see Lall, 1992; Pack and Saggi, 1997). 
This study was inspired by the importance of human capital for economic development and technology diffusion in developing countries. For this purpose, the study aims to analyze the determinant factors on human capital intensity levels of the suppliers with emphasize on foreign ownership and R\&D activities in Turkish automotive industry. The study does use survey data collected through face-to-face questionnaire with the top-managers of the supplier firms operating in the industry. To analyze the determinant factors on HCS of the firms would require a large number of detailed micro data gathered at firm level. This kind of data is not available from national statistical offices so it is necessary to collect this data by field survey. To the best of our knowledge no published similar empirical study and survey exists in Turkey. Hence, we focus on this type of empirical study in this paper and we believe that future research should be focus on these type studies based on detailed micro level data collected through case studies.

The rest of the paper is organized as follows. Next section presents a brief survey of theoretical and empirical literature on human capital, technology spillovers and FDI, respectively, with a specific focus on their connection with economic growth and development. Also, the hypotheses tested in the study are revealed. In the section after that we present our data set, explain the empirical methodology of the study and provide descriptive statistics. The following section discusses and evaluates the results obtained. The final section concludes the paper.

\section{Literature Review}

Human capital is defined as the knowledge and skill base of the workers acquired and developed through both education (general human capital) and professional experience (specific human capital) (Teixeria and Lehmann, 2014, 737). Developing countries think that FDI gives rise to technology diffusion (Borensztein et. al., 1998) through human capital. FDI is generally conducted by multinational companies (MNCs) of the developed countries so they are seen by the developing countries a primary channel for accessing to state-of-the-art technologies. Empirical studies show that human capital is one of the important determinants of FDI (Mengistu and Adhikary, 2011). The findings of some studies justify this by indicating that FDI is the most important factor that impacts positively on the economic development and growth in developing countries. These studies concede that FDI is an important channel through which technology diffusions have been provided from developed countries (firms) to developing ones (firms) (Borensztein et. al., 1998; Xu, 2000). Also, the findings of these studies indicate that when compare it with domestic investment the technology spillovers through FDI flows have more positively impact on the economic growth and development level of the developing countries if they have a pleasing level of HCS. In order to get benefit from FDI, these studies propose that the skilled and quality level of the HCS plays an important role by emphasizing the role of the education level. 
In his "endogenous growth theory", Romer (1986; 1990) also underlined the important role of the human capital for the developing countries. According to Romer, firms which are using state-of-the-art technologies and productive manufacturing techniques in the host country employ qualified human capital, and this give rise to acquiring of more foreign technologies and to benefit more from FDI flows, and in the end he proposes that this would give rise to economic growth. Blomström and Kokko (1997), in their study, indicate a positive relationship between the benefits of FDI and HCS of the firms in host country. In sum, it is expected that host countries which have highly qualified HCS and a high technological capability attract MNCs with advanced technologies. Actually MNCs prefer to invest and establish their highly technological R\&D and design departments in such host countries specified above (for the studies on the MNCs, and motives of them about whether to invest or not in developing countries please see Lall, 1992; Dunning, 1979 and 1993; Narula and Dunning, 2000; Narula and Driffield, 2012). As well, in the literature, it is admitted that the quality of relationships created with MNCs has positively related with the HCS of the firms in host country. Hence, in order to get benefit from the FDI flows, it is a necessary condition for the recipient firms - but not sufficient - to have a certain level of skilled HCS (Lall, 1997; Lall and Narula, 2004).

As proposed in the literature, the qualified HCS of recipient firms in host country determines the benefiting level from technology spillovers of foreign firms. Put differently, it can be said that the HCS of the firms in host country is more important than to be able to access the technologies of foreign firms and to benefit from FDI (Görg and Strobl, 2003). Hence, having low qualified HCS could be a disadvantage for the firms (Bell and Pavitt, 1997). The findings of Portelli and Narula (2004), in their study for Tanzania, show that larger technology gaps due to HCS between local and foreign firms produce lower quality technological spillovers. Here, technology gap term is utilized to cite the absorptive capacity level of the firms. It is commonly interpreted as the distance between source firm (country) and recipient firm (country) in terms of their technological development levels based on various statistical indicators such as R\&D expenditure, number of the R\&D personnel, and number of patents acquired (see Borensztein, et. al., 1998; Xu, 2000). In a similar way, Narula (2004) also indicated that countries which have low qualified HCS acquire FDI flows with low level technologies. Also, Borensztein et al. (1998) showed that higher productivity growth from FDI depend on the level of HCS. In other study, Narula and Marin (2003) affirm that firms with high qualified HCS benefit from technology spillovers and FDI. Xu (2000) also indicates that qualified HCS of the host country plays a critical role in order to get benefit from technology diffusion.

Acquiring of the technology by recipient firms requires skilled HCS. The recipient firms can assimilate the transferred technology into products and production processes by using their human capital (see Nelson and Winter, 1982; Lall, 
1996; Kim, 1997; McKelvey, 1998; Wagner and Sternberg, 1985; Collins, 2001; Goffin and Koners, 2011). The experience and know-how level of the personnel, which can be acquired in many years through practice, education, training, and research activities, determines the skilled level of human capital (for further details see Ernst and Kim, 2002). Human capital capability of a firm, which is determined by accumulation of skills, can be considered as a continuous process. It is suggested that receiver firms need to improve their HCS in order to internalize the transferred technology into production.

In the literature, empirical studies on the determinants of human capital are very scarce, they are mainly theoretical which cover the opinions of authors, and they are in the structure of literature reviews (for further details see OECD, 2001; Teixeria and Lehmann, 2014). One of the important empirical studies in this area is Narula and Marin's (2003) study for Argentina. They compare firms with foreign ownership versus domestic firms regarding to their quantity and quality levels of HCS. According to literature available, foreign ownership status, technological capabilities in terms of R\&D and innovation, firm size, and export intensity are the main factors that affect the human capital intensity of the firms.

Advanced technologies demand qualified and skilled personnel, therefore quantity and quality of the HCS of the firms is generally used as a proxy for technology base of the firm. Therefore, foreign firms may decide to cooperate with a local firm in host country if it has qualified human capital. Findings of the studies show that MNCs with high technology prefer to invest and cooperate with local firms with high qualified HCS. According to literature, firms with foreign ownership are quite more capable than the local firms because they employ more skilled human capital. The technological capabilities of these firms show itself in the productivity level. The most distinct aspects of these firms are that they possess leading engineering skills, they have a separated R\&D department in the plant, they perform high-technology production, they hire more qualified workers, and most of them have foreign share in their capital (Sönmez, 2013). Therefore, it is seen crucial for local firms in host country to have certain level of qualified HCS in order to cooperate with foreign firms and benefit from their state-of-the-art technologies (Keller, 1996). Hence, our first hypothesis is that firms with foreign ownership tend to be more human capital intensive than firms without foreign ownership.

The other factor on the human capital is the R\&D capability of the firms. Dealing with R\&D and innovation activities are seen the key factors that positively impact on the HCS of firms (see Lall, 1992 for further details). The studies point out that existence of foreign firms in the markets positively affects the production and productivity capabilities of the firms which have higher R\&D capability due to skilled HCS (for further details see Blalock and Gertler, 2004; Kinoshita, 2001; Kathuria, 2000). Thus, our second hypothesis is that conducting R\&D activities positively impacts on the suppliers' HCS level. 
It is expected that larger size firms (in terms of turnover, production, employment) employ more skilled human capital because small firms do not have enough human capital to compete with foreign firms and to absorb the technologies used by foreign firms. Some studies confirmed this hypothesis (Aitken and Harrison, 1999), whereas some studies find the opposite results (Girma and Wakelin, 2001; Sinani and Meyer, 2004). Thus, we also want to analyze the way of the effect of this factor on the human capital intensity of the suppliers by this study.

In the literature, it is discussed that firms with export orientation less benefit from technology spillovers in host country, because they already make manufacturing at high technological level for overseas markets and they encounter substantive competition in these markets. Thus, it is considered that technological capabilities of the export oriented firms are very high, and they employ highly qualified HCS so they do not need to create comprehensive connections with foreign firms in host country (Blomström and Sjöholm, 1999). This theory suggests that local firms with no exporting structure are benefited more from technology spillovers in host country. In other words, exporting firms exposed to international competition use advanced technologies and their technological capabilities are high. Therefore, our next hypothesize is that export orientated firms employ more skilled human capital.

According to the literature available, the studies on the determinants of human capital have revealed mixed results so it is difficult to reach an exact outcome on the determinant factors. On the other hand, the common point of the studies they agreed that HCS plays a very important role to utilize positively from technology spillovers (Crespo and Fontoura, 2007). To the best of our knowledge, there has been no similar study conducted in the Turkish automotive industry on this subject. Therefore, the findings obtained here on the determinants of human capital are the first findings in the automotive industry and they are very important, while benchmarking of the findings could not be possible. Moreover, this study may serve to large-scaled empirical studies depend on survey data at micro-level setting an example for them.

\section{Data}

\section{Methodology}

The empirical analysis performing to analyze the factors which impact on the human capital intensity level of the firms is based on primary firm-level survey data. The data were collected by quantitative research methods through specifically designed face-to-face questionnaire survey (the research was financially supported by TUBITAK with a research grant under 1002-short term R\&D funding programme). We employed this study on the supplier firms in Turkish automotive industry. The main motivations behind choosing this particular industry in order to study human capital can be summarized by this way: it has become the primary industry in Turkey, it is dominated by MNCs, it 
draws most of the FDI and host much of the FDI flows in Turkey, its share is very high in Gross Domestic Product (GDP) and total exports of Turkey, it is very competitive on a global scale, firms in the industry perform excessive innovation and R\&D activities, there are strong strategic relations between customers and suppliers, it has become a strategic industry and targeted by the Turkish governments (for further details see Sönmez, 2013).

Although credible statistical data are not available, it is anticipated that more than 3000 suppliers (1225 for NACE342 and 2525 for NACE343) operate in Turkish automotive industry according to statistics from ISSS database (2008). In the selection of the sample, judgment sample method was employed due to special characteristics of the industry. These are that high proportion of the suppliers are small-scale (according to TurkStat statistics, 90 percent of the suppliers are less than 50 employees), operating for replacement market, and producing for raw material. Also, low proportion of the suppliers are producing OEM parts, performing R\&D activities, and exporting. Hence, the case study is mainly concentrated on suppliers conducting R\&D activities, cooperating with automotive main manufacturers (such as Toyota, Mercedes, and Ford in Turkey), being first-tier (direct) suppliers of the manufacturers, being institutionalized, making exports, and being medium or large-sized. There is no any exact information, but according to various statistics it is believed that the number of the suppliers which have the above specified characteristics is nearly 300-350 in the industry. By these reasons, in the selection of the sample, the all 298 suppliers which are the members of TAYSAD (stands for association of automotive parts and components manufacturers) were selected as target sample, because it is the only representative of the supply industry. It represents nearly 65 percent of the output and 70 percent of exports of the industry, and its members employ nearly 80,000 people. Therefore, 227 members (76 percent) of the TAYSAD operating in the four cities of Marmara region (Istanbul, Izmir, Bursa, Kocaeli), the main land of the industry in Turkey, were taken as basic sample. In the implementation phrase of the survey, it was needed to increase the number of sample because some of the suppliers in sample rejected to join the survey. Therefore, a total of another 71 suppliers operating in Marmara region were also added to the sample (227) after detailed scanning of nearly 3000 firms in the industry. In the fieldwork of the survey, total 298 suppliers were contacted in total seven months from February to August in 2010. In this process, questionnaire surveys were successfully conducted face-to-face with the top-executives of the 165 supplier firms (R\&D manager, production manager, executive director, product development manager etc.), with a response rate of 55.4 percent. When surveyed statistics on total employment $(47,366)$ and total turnover (nearly TL 9B; or USD 5,7B) of the suppliers are compared with ISSS database (2008) (in terms of the USD, total turnover of the suppliers was USD 7,3B in 2008), it is seen that the surveyed sample successfully represents 55 percent of the total employment, and 66 percent of the total turnover of the supply industry (NACE342 and NACE343 together). 


\section{Variables and Descriptive Statistics Dependent Variables}

In the empirical analysis, answers to the questions in the characteristics of statistical data and two binary data in terms of the firm structure were used in order to avoid respondents' perception bias. These eight statistical questions are the total number of the employment, total number of engineers / white-collar / blue collar personnel, total sales of the firm, foreign ownership in total capital of the firm, total export and establishment date. Also, two binary data questions are having a R\&D department and being a first-tier (direct supplier) of at least one automotive main manufacturer located in Turkey. Actually, we are interested in examining the factors that impact on different levels of human capital intensity of the suppliers. By using these data, three proxies which show different quality levels of the suppliers regarding the HCS are calculated and used as dependent variables:

(1) Engineer intensity is calculated as the share of engineer personnel in total employment. We assume that this variable represents the ratio of top skilled workers over total employment. In other means, this variable actually represents industry- or firm-specific human capital intensity demanded by suppliers, so we call it specific-human capital intensity. According to survey data, the mean (11.33) and median (7.6) numbers of foreign suppliers with respect to engineer intensity are higher than local suppliers (mean: 6.79, median: 5.26) (significant at 1 percent; t-test).

(2) White-collar intensity is calculated as the share of white-collar employees in total employment. It represents the ratios of educated or schooled workers in total employment. This variable includes generally the administrative personnel such as managers, supervisors, directors, executive managers, and accountants. In other means, this variable presents the general-human capital intensity of the suppliers. In terms of white-collar intensity, mean (20.90) and median (16.16) numbers of foreign suppliers are also higher than local suppliers (mean: 16.6, median: 14.84) (significant at 5 percent level: t-test).

(3) Education intensity is the ratio of sum of the total engineers and whitecollar personnel over total employment. This variable is constructed in order to test the effect of first two human capital intensities (engineer and whitecollar intensity) together. We assume that this proxy represents the generaland specific-human capital intensity together, and therefore, we call it education intensity.

The above three indicators are formed in order to get informed about the human capital intensity levels of the surveyed firms. The statistical data above on the human capital structure reveal that foreign suppliers employ more highlyqualified personnel than local suppliers. A high amount of qualified human 
capital may be an important proxy for the suppliers' absorptive capacity level, advanced production and technological capabilities, since producing complex and high-tech products, cooperating with automotive main manufacturers, operating with state-of-the-art production technologies, performing design, R\&D and innovation activities require having a highly-skilled HCS. The statistics above on the three constructed human capital intensities of the suppliers confirm this view that the absorptive capacity level of the foreign suppliers is also higher than that of the local suppliers, and this gives rise to high qualified HCS for foreign suppliers.

\section{Explanatory Variables}

By using survey data, six explanatory variables related to characteristics, technology capabilities and customer relationships of the suppliers are calculated. These variables include the followings:

(1) Foreign is a dummy variable, and takes the value of 1 if the foreign ownership in the total capital of the supplier is at least 10 percent and 0 otherwise. In our survey, the number of the foreign suppliers with at least 10 percent foreign ownership is 45 (27 percent), and much of these suppliers (16 suppliers) are in joint venture structure with a foreign capital share between 40 percent and 69 percent. There are two reasons why we use 10 percent cut-off point: Firstly, it is in accordance with the OECD, UNCTAD and IMF's definitions. Secondly, the models performed by using different specifications of foreign share (higher than 50 percent, higher than 69 percent, or 100 percent) for robustness check could not produce significant results. Foreign suppliers possibly have superior technology capabilities compared to local suppliers because they possess tangible and intangible assets, and they conduct advanced production activities that need high skilled level of HCS. Moreover, they are generally the affiliates of MNCs located abroad, and they acquire necessary manufacturing information, technology and knowledge regarding to product, which necessities qualified employees, from the parent MNCs. Hence, we hypothesize that foreign suppliers employ more skilled personnel than local suppliers.

(2) Firm age is the natural logarithm of the age of supplier calculated by subtracting the establishment year of the supplier from 2010 (the year when the survey was conducted). According to survey data, 80 percent of the local suppliers were established after the year of 1970, and 36 percent of the foreign suppliers were established 2000 onwards. Also, foreign suppliers are younger (mean, 19) than local suppliers (mean, 29) (significant at 1 percent level; t-test). This variable could be a proxy that indicates the experience of the suppliers in the automotive industry. The higher experience for the supplier may give rise to high-qualified and skilled HCS, more business networks, and trust-based strategic relationships with the customers. On the other hand, the lesser experience in the market may have some 
disadvantages such as lack of human capital, experience, financial support, and technology capabilities. Therefore, young suppliers may act more aggressively in contradiction to the older suppliers, and they may steal skilled and qualified human capital from older suppliers in the market to compete successfully with them and to survive.

(3) Firm size is measured as the natural logarithm of the total employment of the supplier. According to survey data, average number of the employees for all suppliers is 294, and 51 percent of the suppliers are medium-sized (50250 employees), 40 percent are large-sized (250 and more employees), and only 9 percent are small-sized (less than 50 employees). When we look at the foreign suppliers, we see that 48 percent of them are large-sized, and 45 percent is by medium-sized suppliers. In the empirical studies, this variable is generally used as a proxy for a set of variables such as scale of the firm, human resources, availability of financial resources, labor division within firm, production and technology capabilities. In addition, it is also admitted that this variable may affect the HCS of the suppliers, since suppliers depend on their size may demand higher or lesser qualified human capital from the market depending on their production activities. Larger suppliers performing low technological production activities may be self-sufficient and demand less qualified human capital, whereas smaller suppliers performing high technological production, R\&D and innovation activities may demand high qualified workers. This variable may potentially affect the HCS levels of the suppliers positively or negatively, hence, the effect of this variable on human capital intensity remains an empirical issue.

(4) Export intensity is calculated as the ratio of exports to total sales. According to survey statistics, foreign suppliers are more export-oriented (mean: 43.78) than their local counterparts (mean: 34.53, significant at 10 percent level, t-test). Also, at least 50 percent of the foreign suppliers export 40 percent of their total sales to foreign markets (median: 40). The suppliers dealing with foreign trade require skilled human capital and high technological capability in terms of production and production process (quality control, testing, know-how, delivery time, low defect rate, efficiency, design capability etc.) in order to cope with high competition in global markets. Therefore, the summary statistics on foreign trade may imply that foreign suppliers who make more production for the overseas markets employ more qualified HCS. For these reasons, this variable may also be a proxy for the suppliers' absorptive capacity level. The intense competition on foreign markets may oblige suppliers to employ more qualified personnel, and it can be suggested that the suppliers who make more production for the overseas markets demand higher amount of qualified human capital. In sum, this variable may exert a positive influence on supplier's human capital intensity. 
(5) $R \& D$ department is a dummy variable and takes the value of 1 if supplier has a R\&D department, 0 otherwise. According to survey data, 133 (81 percent) suppliers perform R\&D activities, while only 99 of them (60 percent) have an R\&D department. This variable reveals that suppliers carry out their R\&D activities at an advanced level, and indicates that suppliers have a minimum level of technological competence, specific background and knowhow related to production technology. This can increase the suppliers' demand for high-qualified HCS in the field of technology. Hence, this variable may act as a proxy for the supplier's absorptive capacity level. This means that a higher level of absorptive capacity may be an indicator for the supplier's higher qualified human capital in such R\&D activities (such as quality control, design, design verification, and product development). In sum, it is expected a positive relationship between this variable and the supplier' demand for top-qualified human capital in the field of technology.

For the robustness check, two proxies for R\&D were also constructed by using survey data; (1) logarithm of the R\&D expenditures and (2) R\&D intensity (the share of R\&D expenditures in total sales). These, however, yield insignificant results in the regression analyses because of high number of missing values and high correlation rates with engineer intensity dependent variable. Based on survey data, mean value of the R\&D intensity are higher for foreign suppliers. This means that foreign suppliers spend more money on R\&D activities than the local suppliers on average. According to median value of R\&D intensity, at least 50 percent of the foreign suppliers spend 2 percent of their total sales on R\&D whereas local suppliers spend 1 percent. This indicates that foreign suppliers make more investment on R\&D, and this may be the reason why they have more highly-skilled HCS.

(6) Direct Supplier Firm (DSF) is also a binary variable and indicates that supplier is being the first-tier supplier of at least one automotive main manufacturer operating in Turkey, 0 otherwise. According to the data, 132 (80 percent) suppliers are the first-tier supplier of at least one manufacturer in Turkey. Also, 39 (87 percent) out of the 45 foreign suppliers are the firsttier suppliers. It is expected a positive relationship between being a DSF and suppliers' human capital intensity, since working directly with the main manufacturers require production of the sophisticated part and components, and fulfill various high manufacturing standards in terms of production, hence more demand for qualified human capital. This assumption has been tested by introducing this binary variable in the model. Moreover, this variable may be a proxy for absorptive capacity level of the supplier due to same reasons mentioned above.

First three explanatory variables defined above show the basic characteristics of the suppliers regarding human capital. Fourth variable show the export-oriented level of the firms, and it is assumed that export-oriented suppliers exert advanced technological production capabilities and therefore they demand 
higher qualified HCS. Fifth variable indicates the R\&D capabilities and activities. And the last one shows the cooperation with manufacturers and hence technological capabilities of the suppliers.

\section{Model}

In order to analyze the determinant factors on human capital intensity of the suppliers discussed previously, OLS regression analysis will be used. The basic model to be estimated is as follows:

$$
Y=\beta_{0}+\beta_{1} X+e
$$

Where, $Y$ indicates the dependent variable, and $X$ explanatory variables. The correlation matrix and descriptive statistics of the variables are provided in Table 1. As it can be seen from the Table 1 some of the correlations between explanatory variables are significant, however they are below $+/-.40$ and most are below .30, therefore multicollinearity will not occur and will not affect the interpretations of the analysis results.

Table 1: Descriptive Statistics and Correlation Matrix

\begin{tabular}{|c|c|c|c|c|c|c|c|c|c|}
\hline & (1) & (2) & (3) & (4) & (5) & (6) & (7) & $(8)$ & (9) \\
\hline $\begin{array}{l}\text { (1) Engineer } \\
\text { intensity (\%) }\end{array}$ & 1 & $\begin{array}{l}0.204 \\
* * *\end{array}$ & $\begin{array}{r}0.688 \\
* * *\end{array}$ & $\begin{array}{r}0.238 \\
* * *\end{array}$ & $\begin{array}{l}-0.253 \\
* * *\end{array}$ & -0.207 & -0.016 & $\begin{array}{r}0.162 \\
* *\end{array}$ & 0.104 \\
\hline $\begin{array}{l}\text { (2) White-Collar } \\
\text { intensity (\%) }\end{array}$ & & 1 & $\begin{array}{r}0.851 \\
* * *\end{array}$ & $\begin{array}{r}0.160 \\
* *\end{array}$ & -0.082 & $\begin{array}{r}-0.224 \\
* * *\end{array}$ & 0.027 & 0.012 & -0.056 \\
\hline $\begin{array}{l}\text { (3) Education } \\
\text { intensity (\%) }\end{array}$ & & & 1 & $\begin{array}{r}0.247 \\
* * *\end{array}$ & $\begin{array}{r}-0.196 \\
* *\end{array}$ & $\begin{array}{r}-0.277 \\
* * *\end{array}$ & 0.011 & 0.096 & 0.015 \\
\hline (4) Foreign & & & & 1 & $\begin{array}{r}-0.387 \\
* * *\end{array}$ & 0.094 & $\begin{array}{r}0.141 \\
*\end{array}$ & -0.000 & 0.102 \\
\hline $\begin{array}{l}\text { (5) Firm age } \\
\text { (log) }\end{array}$ & & & & & 1 & $\begin{array}{r}0.315 \\
* * *\end{array}$ & -0.068 & 0.106 & 0.120 \\
\hline $\begin{array}{l}\text { (6) Firm size } \\
\text { (log) }\end{array}$ & & & & & & 1 & $\begin{array}{r}0.187 \\
* *\end{array}$ & $\begin{array}{r}0.184 \\
* *\end{array}$ & $\begin{array}{r}0.243 \\
* * *\end{array}$ \\
\hline $\begin{array}{l}\text { (7) Export } \\
\text { intensity (\%) }\end{array}$ & & & & & & & 1 & 0.127 & -0.120 \\
\hline $\begin{array}{l}\text { (8) R\&D } \\
\text { Department }\end{array}$ & & & & & & & & 1 & 0.056 \\
\hline (9) DSF & & & & & & & & & 1 \\
\hline $\mathrm{N}$ & 161 & 161 & 161 & 165 & 165 & 161 & 165 & 165 & 165 \\
\hline Mean & 8.03 & 17.68 & 25.72 & 0.27 & 3.13 & 5.20 & 37.05 & 0.60 & 0.80 \\
\hline SD & 8.55 & 11.82 & 15.94 & 0.45 & 0.74 & 0.99 & 29.35 & 0.49 & 0.40 \\
\hline Min. & 0 & 0 & 6.47 & 0 & 0 & 2.71 & 0 & 0 & 0 \\
\hline Max. & 66.20 & 88.31 & 100 & 1 & 4.32 & 8.01 & 100 & 1 & 1 \\
\hline
\end{tabular}




\section{Results}

Estimation results on the determinants of human capital intensity are presented in Table 2. Before discussing the results for explanatory variables, as can be seen from the table F-statistics indicate that models are highly significant $(p<0.01)$. This means that three regression models as a whole have statistically significant predictive capability. Also, heteroscedasticity problem was tested by using White test statistics. The null hypothesis of homoscedasticity in the error term was rejected in engineer and education intensity models, however White's test indicates heteroscedasticity problem in white-collar intensity model $(p<0.01)$. In order to tackle this problem, estimated robust standard errors were used for the explanatory variables of white-collar intensity model.

Table 2: Determinants of the Human Capital Intensity of the Automotive Suppliers in Turkey

\begin{tabular}{|c|c|c|c|c|c|c|}
\hline & \multicolumn{6}{|c|}{ Dependent variable } \\
\hline & \multicolumn{2}{|c|}{ Engineer intensity } & \multicolumn{2}{|c|}{ White-collar intensity } & \multicolumn{2}{|c|}{ Education intensity } \\
\hline & Coef. & $\mathrm{p}$-value & Coef. & $\mathrm{p}$-value ${ }^{\mathrm{a}}$ & Coef. & $\mathrm{p}$-value \\
\hline Foreign & $\begin{array}{r}3.714 \\
* *\end{array}$ & 0.022 & $\begin{array}{r}5.855 \\
*\end{array}$ & 0.065 & $\begin{array}{r}9.569 \\
* * *\end{array}$ & 0.002 \\
\hline Firm age (log) & $\begin{array}{r}-1.654 \\
*\end{array}$ & 0.098 & 1.453 & 0.366 & -0.201 & 0.914 \\
\hline $\begin{array}{l}\text { Firm size } \\
\text { (log) }\end{array}$ & $\begin{array}{r}-2.187 \\
* * *\end{array}$ & 0.003 & $\begin{array}{r}-3.426 \\
* * *\end{array}$ & 0.005 & $\begin{array}{r}-5.613 \\
* * *\end{array}$ & 0.000 \\
\hline $\begin{array}{l}\text { Export } \\
\text { intensity (\%) }\end{array}$ & -0.003 & 0.895 & 0.019 & 0.575 & 0.016 & 0.708 \\
\hline $\begin{array}{l}\text { R\&D } \\
\text { Department }\end{array}$ & $\begin{array}{r}3.771 \\
* * *\end{array}$ & 0.004 & 1.199 & 0.593 & $\begin{array}{r}4.969 \\
* *\end{array}$ & 0.042 \\
\hline DSF & $\begin{array}{r}3.064 \\
*\end{array}$ & 0.065 & -0.588 & 0.786 & 2.476 & 0.424 \\
\hline Constant & $\begin{array}{r}19.037 \\
* * *\end{array}$ & 0.000 & $\begin{array}{r}28.476 \\
* * *\end{array}$ & 0.000 & $\begin{array}{r}47.513 \\
* * *\end{array}$ & 0.000 \\
\hline$N$ & 161 & & 161 & & 161 & \\
\hline F-statistic & 5.790 & 0.000 & 3.38 & 0.004 & 5.598 & 0.000 \\
\hline Adjusted $\mathrm{R}^{2}$ & 0.152 & & 0.059 & & 0.147 & \\
\hline \multicolumn{7}{|l|}{ White's test ${ }^{a}$} \\
\hline chi2(24) & 19.11 & & 43.13 & & 31.30 & \\
\hline Prob > chi2 & 0.746 & & 0.0096 & & 0.145 & \\
\hline
\end{tabular}

$* * * \mathrm{p}<0.01, * * \mathrm{p}<0.05, * \mathrm{p}<0.10$

a : The White's test statistics indicates the presence of heteroscedasticity only for the white-collar intensity model prior to any adjustment, hence $p$-values for that model are related to the estimated robust standard errors. 
According to empirical test results, foreign ownership has positive (and significant) impact on all three human capital intensities as expected. Size of the coefficients on foreign variable is larger and strongly significant $(p<0.01)$ for education intensity, and it appears lower for white-collar intensity, and it is minimum for engineer intensity. These figures indicate that there is a positive relationship between foreign ownership and suppliers' HCS quality. In other words, foreign suppliers are more benefited from HCS but especially more when foreign share is higher. Our results confirm the hypothesis that foreign firms employ more skilled personnel than local firms. One of the reasons may be that foreign firms produce more technological parts and components than their local counterparts. The other reason can be that foreign firms may have a high number of skilled employees that ensure them to compete with local suppliers in host country.

Regression results also show that firm age does have a significant impact only on engineer intensity $(p<0.10)$, and it is negative. This finding indicates that there is a negative relationship between firm age and engineer intensity level of the suppliers, and a one year increase in the age of a supplier reduces by 1.654 points the engineering intensity. This means that the top-qualified human capital demand reduces with the suppliers' experience level, ceteris paribus. In other words, new established supplier firms in the industry employ a high qualified HCS compared to experienced suppliers. This finding may show that accomplished suppliers in the industry maintain a high level of production capabilities and this makes the demand for the qualified HCS unnecessary. By the way younger supplier firms are more benefited from the engineering human capital and this ensures them to compete with older supplier firms. On the other hand, regression results do not produce significant evidence on the white-collar and education intensity models.

Regarding the firm size, regression results show that it is the only variable that has negative (and highly significant) impact on all three human capital intensity measures. This result reveals that smaller suppliers with respect so size tend to employ more intensive human capital. When we compare the coefficients of firm size on human capital intensities, we see that the size of coefficients on education intensity is larger (in absolute terms), while on engineer intensity is smaller (in absolute terms). This means that smaller suppliers benefited more from the high skilled human capital intensity. Actually, this variable may be a proxy for a core set of variables (scale of the firm, costs, financial resources, human resources, know-how) potentially affecting production, technology capabilities, innovation and R\&D activities of the suppliers. Therefore, it may affect negatively human capital intensity of the suppliers since large suppliers may be self-sufficient and demand less skilled HCS. On the other hand, this result reveals that smaller suppliers may act more aggressively in contradiction to the larger suppliers with respect to qualified HCS that enable them to compete with larger suppliers. 
According to the regression findings, the only explanatory variable that has no any statistically significant effect on all the senses of human capital intensities is the export intensity. We mentioned earlier that export oriented suppliers may have many superiorities in terms of technological competence, for example, they conduct product innovation activities, competing with rival firms in global markets, and manufacturing complex, high-tech and high quality products. Therefore, they require high level of skilled employees. It is quite striking and no clear to explain that the export intensity factor is not reflected on the suppliers' HCS level.

Estimation findings reveal that having a $R \& D$ department and being a direct supplier firm (DSF) have a positive and significant impact on engineer intensity (we call specific HCS of the supplier), while there is no any significant impact on white-collar intensity (we call general HCS of the supplier). These two factors (R\&D department and DSF) are assumed as important indicators of absorptive capacity of the suppliers, since these could be a proxy for the supplier's HCS, technological capability related to products. These point out the importance of performing $R \& D$ activities and being a first-tier supplier of automotive main manufacturers on high qualified human capital. Hence, suppliers employ more qualified HCS in order to improve their skills and technology capabilities. A highly-qualified HCS is also seen an important factor by the automotive main manufacturers in order to select their suppliers and to decide to collaborate with them. In these respects, our findings confirm that these two explanatory variables play very important role on the suppliers' HCS level.

\section{Conclusion}

Contributing to the literature by studying the determinant factors on different human capital intensity levels of the firms with a special emphasize on foreign ownership is the main purpose of the paper. We employed this study on the supplier firms in Turkish automotive industry by using collected data at firm level through questionnaire survey with the 165 suppliers (55.4 percent response rate). Overall, our empirical study emphasized that foreign ownership, being a first-tier supplier, and performing R\&D activities (having an R\&D department) affect positively engineer intensity level (specific-HCS of the suppliers), while being older and larger firms affect negatively this intensity. On the other hand, white-collar intensity level (general-HCS of the suppliers) is affected positively from foreign ownership, and negatively from the firm size variable. The findings can be summarized as foreign ownership has positive (and significant) impact on all senses of suppliers' human capital intensity as expected, and its impact is highest on specific-HCS. Being an older or larger firm negatively (and significantly) impacts a supplier's specific-HCS, while performing R\&D activities and being a first-tier supplier impacts positively (and significantly). These findings reveal that smaller and younger first-tier foreign suppliers performing R\&D activities employ more skilled and educated HCS. Otherwise, the effect of 
export intensity on HCS level is not statistically significant. To conclude, implicit factors behind the findings obtained should be specifically analyzed in another case study.

\section{References}

Aitken, B. J. and Harrison, A. E. (1999). Do Domestic Firms Benefit from Direct Foreign Investment? Evidence from Venezuela. American Economic Review, 89 (3), 605-618.

Barro, R. and Sala-i-Martin, X. (1995). Economic Growth. Cambridge, MA: McGraw-Hill.

Bell, M. and Pavitt, K. (1997). Technological Accumulation and Industrial Growth: Contrasts between Developed and Developing Countries. D. Archibugi and J. Michie (Ed.). In Technology, Globalisation and Economic Performance (83-137). Cambridge University Press.

Blalock, G. and Gertler, P. (2004). Firm capabilities and Technology Adoption: Evidence from Foreign Direct Investment in Indonesia. Working Paper, Department of Applied Economics and Management, Cornell University, Ithaca, New York.

Blomström, M. and Kokko, A. (1997). How Foreign Investment Affects Host Countries. Policy Research Working Paper, No 1745, the World Bank: Washington, DC.

Blomström, M. and Sjöholm, F. (1999). Technology Transfer and Spillovers: Does Local Participation with Multinationals Matter?. European Economic Review, 43 (4-6), 915-923.

Borensztein, E., Gregorio, J. and Lee, J. W. (1998). How Does Foreign Direct Investment Affect Economic Growth?. Journal of International Economics, 45, 115-135.

Collins, H. M. (2001). Tacit Knowledge, Trust and the Q of Sapphire. Social Studies of Science, 31 (1), 71-85.

Crespo, N. and Fontoura, M. P. (2007). Determinant Factors of FDI Spillovers What Do We Really Know. World Development, 35 (3), 410-425.

Dosi, G. (1988). Sources, Procedures and Microeconomic Effects of Innovation. Journal of Economic Literature, 26 (3), 1120-1171. 
Dunning, J. (1979). Explaining Patterns of International Production: In Defence of the Eclectic Theory. Oxford Bulletin of Economics and Statistics, 41 (2), 269-295.

Dunning, J. (1993). Multinational Enterprises and the Global Economy. Wokingham, UK: Addison-Wesley Publishing Company.

Ernst, D. and Kim, L. (2002). Global Production Networks, Knowledge Diffusion, and Local Capability Formation. Research Policy, 31, 1417-1429.

Girma, S. and Wakelin, K. (2001). Regional Underdevelopment: Is FDI the Solution? A Semi-Parametric Analysis. GEP Research Paper 2001/11, University of Nottingham.

Goffin, K. and Koners, U. (2011). Tacit Knowledge, Lessons Learnt and New Product Development. Journal of Product Innovation Management, 28 (2), 300-318.

Görg, H. and Strobl, E. (2003). Multinational Companies, Technology Spillovers and Plant Survival. Scandinavian Journal of Economics, 105 (4), 581-595.

ISSS database. (2008). Turkstat's Annual Industry and Service Statistics Survey Database.

Kathuria, V. (2000). Productivity Spillovers from Technology Transfer to Indian Manufacturing Firms. Journal of International Development, 12 (2), 343369.

Keller, W. (1996). Absorptive Capacity: On the Creation and Acquisition of Technology in Development. Journal of Development Economics, 49, 199227.

Kim, L. (1997). Imitation to Innovation: The Dynamics of Korea's Technological Learning. Boston, USA: Harvard Business School Press.

Kinoshita, Y. (2001). R\&D and Technology Spillovers through FDI: Innovation and Absorptive Capacity. CEPR Discussion Paper DP2775, Centre for Economic Policy Research, London.

Kuznets, S. (1966). Modern Economic Growth: Rate, Structure, Spread. New Haven: Yale University Press.

Lall, S. (1992). Technological Capabilities and Industrialization. World Development, 20 (2), 165-186.

Lall, S. (1996). Learning from the Asian Tigers. London: MacMillan Press. 
Lall, S. (1997). East Asia. J. H. Dunning (Ed.). In Governments, Globalization, and International Business (407-430). Oxford: Oxford University Press.

Lall, S. and Narula R. (2004). Foreign Direct Investment and Its Role in Economic Development: Do We Need a New Agenda?. The European Journal of Development Research, 16 (3), 447-464.

Lee, C. (2008). Innovation, Productivity and Exports: Firm-Level Evidence from Malaysia. Nottingham University Business School University of Nottingham Malaysia Campus, Working Paper Series, March, Vol. 2008-06.

McKelvey, M. (1998). Evolutionary Innovations: Learning, Entrepreneurship and the Dynamics of the Firm. Journal of Evolutionary Economics, 8, 157-175.

Mengistu, A. A. and Adhikary, B. K. (2011). Does Good Governance Matter for FDI Inflows? Evidence from Asian Economies. Asia Pacific Business Review, 17 (3), 281-299.

Narula, R. and Dunning, J. H. (2000). Industrial Development, Globalization and Multinational Enterprises: New Realities for Developing Countries. Oxford Development Studies, 28 (2), 141-167.

Narula, R. and Marin, A. (2003). FDI Spillovers, Absorptive Capacities and Human Capital Development: Evidence from Argentina. MERIT-Infonomics Research Memorandum Series, 2003-016.

Narula, R. (2004). Understanding Absorptive Capacities in an Innovation Systems Context: Consequences for Economic and Employment Growth. MERIT Research Memorandum, 2004-003.

Narula, R. and Driffield, N. (2012). Does FDI Cause Development? The Ambiguity of the Evidence and Why it Matters. European Journal of Development Research, 24, 1-7.

Nelson, R. R. and Winter, S. (1982). Evolutionary Theory of Economic Change. Massachusetts: Harvard University Press.

OECD (2001). FDI, Human Capital and Education in Developing Countries. In OECD Development Centre Technical Meeting.

Pack, H. and Saggi, K. (1997). Inflows of Foreign Technology and Indigenous Development. Review of Development Economics, 1(1), 81-98.

Portelli, B. and Narula, R. (2004). Foreign Direct Investment through Acquisitions and Implications for Technological Upgrading. Case Evidence from Tanzania, Merit Research Memorandum. 
Romer, P. (1986). Increasing Returns and Long-Run Growth. Journal of Political Economy, 94 (5), 1002-1037.

Romer, P. (1990). Endogenous Technological Change. Journal of Political Economy, 98 (5), 71-102.

Schumpeter, J. A. (1934). The Theory of Economic Development: An Inquiry into Profits, Capital, Credit, Interest and the Business Cycle. Cambridge, Mass.: Harvard University Press.

Sinani, E. and Meyer, K. (2004). Spillovers of Technology Transfer from FDI: The Case of Estonia. Journal of Comparative Economics, 32, 445-466.

Sönmez, A. (2013). Multinational Companies, Knowledge and Technology Transfer: Turkey's Automotive Industry in Focus, New York, USA: Springer.

Teixeira, A. A. C. and Lehmann, A. T. T. (2014). Human Capital Intensity in Technology-Based Firms Located in Portugal: Does Foreign Ownership Matter?. Research Policy, 43, 737-748.

Wagner, R. K. and Sternberg, R. J. (1985). Practical Intelligence in Real-World Pursuits: the Role of Tacit Knowledge. Journal of Personality and Social Psychology, 49 (2), 436-458.

Xu, B. (2000). Multinational Enterprises, Technology Diffusion, and Host Country Productivity Growth. Journal of Development Economics, 62, 477-493. 